\title{
ESTIMATION OF THE HEAT OF REACTION IN
}

\section{TRADITIONAL CERAMIC COMPOSITIONS}

\author{
S. FERRER; A. MEZQUITA; M.P. GOMEZ-TENA; C. MACHI, C.; E. MONFORT \\ Instituto de Tecnología Cerámica.
}

Asociación de Investigación de las Industrias Cerámicas.

Universitat Jaume I. Castellón. Spain.

Corresponding author: S. Ferrer e-mail: $\underline{\text { salvador.ferrer@itc.uji.es }}$

Phone: 34964342424 Fax: 34964342425

Address: ITC Campus Riu Sec 12006 Castellón. Spain

\begin{abstract}
Most energy studies on the traditional ceramic manufacturing process focus on the firing stage because this is the process stage that consumes the greatest amount of thermal energy. At present in Europe, using typical technologies, about 50\% of the energy input in the firing stage is still lost through the kiln stacks. A key issue in energy studies is the accurate determination of the energy efficiency of the process, an issue that may become crucial in coming years to enable the energy management of different facilities and products to be compared. To reliably determine energy efficiency, accurate determination is required of the energy needed for the necessary physico-chemical transformations to develop in the material in the firing stage. This energy is also the only strictly unrecoverable energy, as the energy contained in other streams could, potentially at least, be partly recoverable. The present study was undertaken to develop an analytical methodology for estimating the heat of reaction of seven different traditional ceramic products, involving a broad spectrum of compositions, with peak firing temperatures ranging from $850{ }^{\circ} \mathrm{C}$ to $1200{ }^{\circ} \mathrm{C}$. The following industrial ceramic compositions were studied: four ceramic tile compositions (red-body stoneware tile, porcelain tile, red-body earthenware wall tile, and white-body earthenware wall tile); two structural ceramics compositions (white brick and roof tile), and a porcelain tableware composition. To estimate the energy involved in the physico-chemical reactions in the firing stage, an analytical methodology was developed, based on
\end{abstract}


the mineralogy data of the unfired body composition and on the enthalpy of formation of the minerals in the fired tiles. The methodology was validated by comparing the results with experimental data.

Keywords: heat of reaction, physico-chemical transformations, energy efficiency, firing, traditional ceramics.

\section{Introduction}

At present in Europe, using typical technologies, large quantities of thermal energy are consumed in traditional ceramic manufacturing processes. These processes are quite similar and consist of stages that differ as a function of the product made. The main production stages are as follows: raw materials preparation (by dry or wet milling), forming (by casting, pressing, or extrusion), drying, firing of the body (in double-fired products), glazing and decorating, and firing (Agrafiotis et al., 2001; Bovea et al., 2010; IPTS. European Commission, BREF, 2007).

Thermal energy consumption takes place mainly in three process stages: wet milling (in which the ceramic slurry may be need to be dried for semi-dry pressing); drying (after forming); and firing. In this manufacturing process, firing accounts for more than $50 \%$ and $70 \%$ of the overall energy consumption when wet and dry milling are used, respectively (Mezquita et al., 2009 and 2014; Monfort et al., 2010).

In traditional ceramics manufacture, from an energy viewpoint, the firing stage is the most important process stage, as it needs to supply sufficient heat for the necessary physico-chemical transformations in the material to develop and to provide the product with the desired technical and aesthetic properties.

The thermal energy needed to fire glazed ceramics usually stems from the combustion of natural gas. However, in the manufacture of structural ceramics, which are mainly unglazed products, other fuels may be used, such as pet coke, coal, or biomass. These fossil fuels give rise to air emissions of $\mathrm{CO}_{2}$, a greenhouse gas, the emissions of which are subject to international control and mitigation measures. 
The present study was undertaken to determine the quantity of energy consumed by the chemical reactions that develop in the ceramic firing stage, i.e. in the heat of reaction. At present, using today's technologies, the heat of reaction constitutes a relatively small fraction (5-20\%) of the overall energy required in industrial firing. It is the only energy that cannot be recovered, in contrast for example to the sensible heat of fired ceramics (which is partially recoverable in the cooling phase) or to combustion gas heat (recoverable using heat exchangers).

From an energy viewpoint, in the firing cycle, the material undergoes both exothermic and endothermic transformations. These need to take place gradually and in a controlled way, as they could otherwise lead to permanent defects in the end product.

The shape of the firing curve (temperature as a function of time) essentially depends on the body composition and, in glazed ceramics, on the nature of the glaze (glossy, opaque, matt, etc.). In general, every traditional ceramic firing cycle includes the following steps:

- Heating: In this step, the unfired products are heated from ambient temperature to about 800 ${ }^{\circ} \mathrm{C}$ (depending on the raw materials composition). This is the step in which outgassing of the ceramic body needs to take place to avoid problems of bloating, bubbles, pinholing, glaze porosity, and colour differences at higher temperatures. Various transformations take place in the material during heating, such as the removal of free water, combustion of organic matter, allotropic transformation of $\alpha$-quartz to $\beta$-quartz, loss of $\mathrm{OH}^{-}$groups in the clays, and carbonate decomposition when the composition contains carbonates. All these chemical reactions lead to a series of internal stresses in the ceramic product owing to gas release, changes in volume, etc. If these stresses exceed the mechanical strength of the as yet "unfired" ceramic product, failure will occur.

- Firing: The actual firing step runs from about $800{ }^{\circ} \mathrm{C}$ to the programmed peak temperature, typically between $850{ }^{\circ} \mathrm{C}$ and $1350{ }^{\circ} \mathrm{C}$, which depends on the product being made. The main physico-chemical transformations take place in this step. These reduce the ceramic material's porosity. They lead to the most important dimensional changes (shrinkage) in low porosity 
products (stoneware and porcelain ware) and to the formation of stable crystalline phases (calcium silicates) in porous products (earthenware wall tiles and structural ceramics).

- Cooling: This begins when the heat input ends. In the cooling step, product temperature decreases from peak temperature to near ambient temperature. In traditional ceramics the cooling rate is essentially constrained by quartz phase transformation at $573{ }^{\circ} \mathrm{C}$, as this produces a volume change that can cause cracking in the product if cooling does not take place uniformly throughout the material, owing to the low thermal conductivity of ceramic materials.

A typical traditional ceramic firing cycle is shown in figure 1. The figure summarises the most important physico-chemical changes that develop during traditional ceramics thermal treatment and the temperature ranges in which these changes occur (Pennisi, 1991). A ceramic firing schedule depends on several factors, the most important being body composition, thickness and geometry of the ceramic product, kiln loading density, and type of kiln. For instance, the schedule time in roller hearth kilns (low product thickness and low kiln loading density) is typically between 30 and 60 minutes, whereas in tunnel kilns (high loading density and thick products), this ranges from 18 to 24 hours.

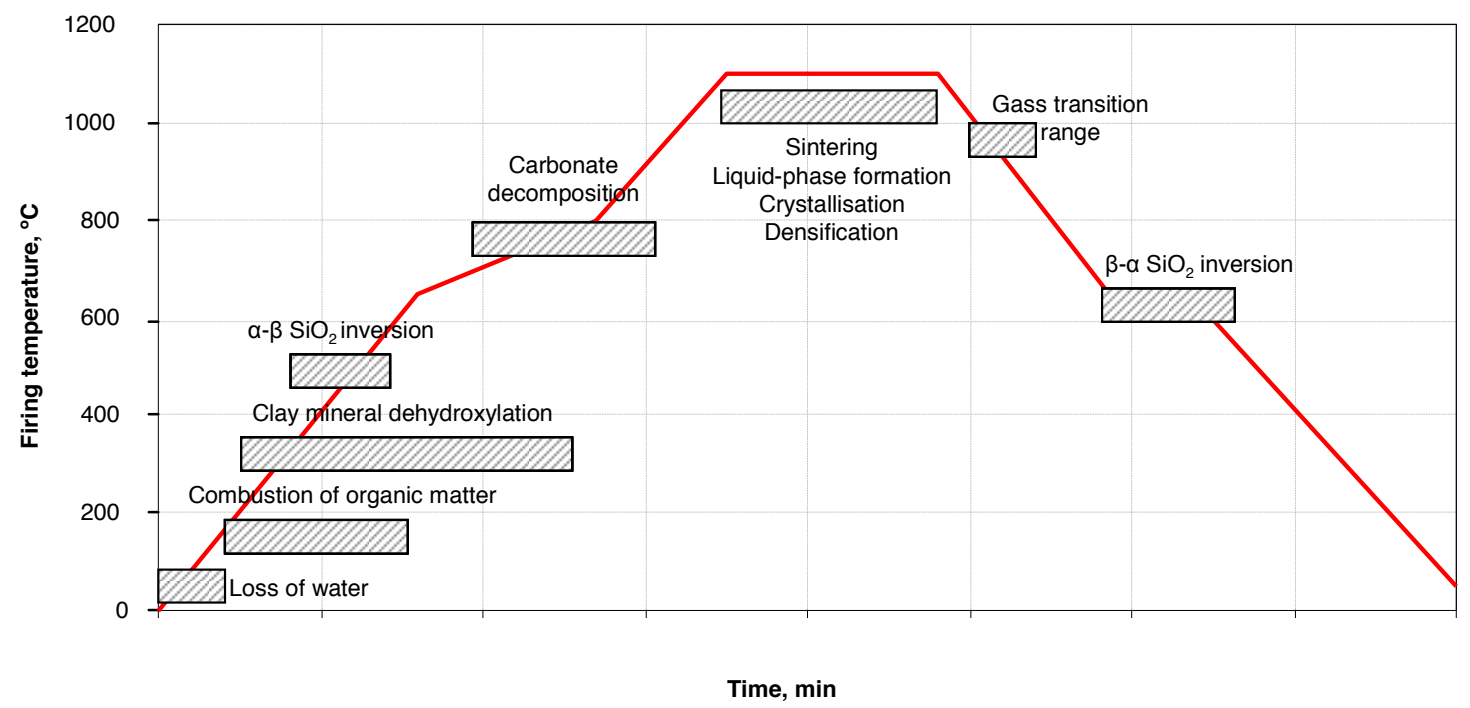

Figure 1. Typical firing curve with the physico-chemical reactions that develop in traditional ceramic compositions.

The raw materials composition plays a very important role, not only in environmental emissions in the firing stage, but also in energy consumption in this stage. The quantities of carbonates, organic matter, 
and other raw materials in the ceramic compositions influence kiln thermal energy consumption, as the energy required to develop the physico-chemical reactions in firing depends on the ceramic composition involved (Mezquita et al., 2009).

Although numerous studies have been conducted on the firing of traditional ceramics (Bernardo et al., 2010; Castelein et al., 2001; Eliche et al., 2011; Macgee, 1926; Madivate et al., 2004; Njoya et al., 2012; Plante et al., 2009; Sánchez et al., 2001; Simpson, 1927; Vogt et al., 2012), mainly addressing technical, environmental, or energy issues, few studies have focused on the energy involved in the physico-chemical transformations that take place (Macgee, 1926; Simpson, 1927; Madivate et al., 2004; Vogt et al., 2012).

This study was undertaken to develop an analytical methodology for estimating the heat of reaction in traditional ceramic compositions. To validate the methodology, differential scanning calorimetry (DSC), an experimental thermal analysis technique, was used, which is briefly described below. To perform the relevant calculations, thermal data (such as the calorific capacities and enthalpies of formation) were required, on which very little information is at present available for these traditional ceramic compositions.

\section{Objective and scope}

In the literature surveyed, no clearly defined methodology was found for determining the heat of transformation in traditional industrial ceramic compositions (Vogt et al., 2012).

The present study was undertaken with the following objectives:

- To define and compare two different methodologies for calculating the energy needed to develop the relevant physico-chemical transformations in ceramic raw materials compositions during the firing stage.

- To analyse the heats of transformation obtained for seven types of traditional ceramic compositions.

The studied ceramic compositions cover a wide variety of traditional products that are fired at peak temperatures ranging from $850{ }^{\circ} \mathrm{C}$ to $1200{ }^{\circ} \mathrm{C}$. Although the maximum theoretical temperature of the DSC instrument used in the experiments was $1350{ }^{\circ} \mathrm{C}$ (as set out below in point 3.2.1), the study was 
limited to compositions fired at peak temperatures below $1250{ }^{\circ} \mathrm{C}$, since the authors' experience in this field indicates that, at temperatures above $1250{ }^{\circ} \mathrm{C}$, the error becomes unacceptable $(>10 \%)$.

\section{Materials used and experimental procedure}

\subsection{Material characterisation}

\subsubsection{End product characteristics}

The study was conducted on seven traditional industrial ceramic compositions: four ceramic tile bodies, two structural ceramic bodies, and a porcelain tableware composition. The ceramic tile and tableware compositions were prepared industrially by wet milling and spray drying the resulting suspensions, whereas the brick and roof tile compositions were prepared by dry milling. The ceramic tile compositions were fired in industrial roller hearth kilns; the other compositions were fired in industrial tunnel kilns. Only the ceramic tiles and tableware were glazed. The main processing details and end product characteristics are summarised in table 1.

Table 1. Main processing details and end product characteristics of the studied compositions.

\begin{tabular}{|c|c|c|c|c|c|c|c|c|}
\hline \multirow{3}{*}{ Reference } & \multirow{3}{*}{ Product } & \multicolumn{5}{|c|}{ Processing details } & \multirow{2}{*}{\multicolumn{2}{|c|}{ End product }} \\
\hline & & \multirow[b]{2}{*}{ Milling } & \multirow[b]{2}{*}{ Shaping } & \multicolumn{3}{|c|}{ Firing } & & \\
\hline & & & & $\begin{array}{c}\text { Peak } \\
\text { temperature } \\
\left({ }^{\circ} \mathrm{C}\right)\end{array}$ & $\begin{array}{l}\text { Total } \\
\text { cycle } \\
\text { (h) }\end{array}$ & Kiln & Glazed & $\begin{array}{c}\text { Water } \\
\text { absorption } \\
(\%)\end{array}$ \\
\hline RBT & $\begin{array}{c}\text { Red-body } \\
\text { stoneware tile }\end{array}$ & Wet & Pressing & 1143 & 0.46 & Roller & Yes & 2.9 \\
\hline PCT & Porcelain tile & Wet & Pressing & 1190 & 0.57 & Roller & Yes & $<0.5$ \\
\hline RWT & $\begin{array}{l}\text { Red-body } \\
\text { earthenware wall } \\
\text { tile }\end{array}$ & Wet & Pressing & 1126 & 0.40 & Roller & Yes & 14 \\
\hline WWT & $\begin{array}{l}\text { White-body } \\
\text { earthenware wall } \\
\text { tile }\end{array}$ & Wet & Pressing & 1140 & 0.51 & Roller & Yes & 17 \\
\hline WBR & White brick & Dry & Extrusion & 850 & 24 & Tunnel & No & 20 \\
\hline RFT & Roof tile & Dry & Pressing & 1019 & 18 & Tunnel & No & 10 \\
\hline PTW & $\begin{array}{l}\text { Porcelain } \\
\text { tableware }\end{array}$ & Wet & $\begin{array}{c}\text { Slip } \\
\text { casting }\end{array}$ & 1000 & 22 & Tunnel & Yes & $<0.5$ \\
\hline
\end{tabular}




\subsubsection{Chemical analysis}

The chemical composition was determined by wavelength dispersive X-ray fluorescence spectrometry (WD-XRF), using a PANALYTICAL model Axios WD-XRF spectrometer with Rh tube and $4 \mathrm{~kW}$ power. Reference materials were used to guarantee measurement traceability.

The samples were prepared as fused beads and pressed powder pellets. To prepare the fused beads, the sample was mixed with a 50:50 mixture of $\mathrm{LiBO}_{2} / \mathrm{Li}_{2} \mathrm{~B}_{4} \mathrm{O}_{7}$ as flux in a $\mathrm{Pt} / \mathrm{Au}$ crucible, adding a solution of LiI as bead-releasing agent. The mixture was then fused using a PHILIPS model Perl'X3 automatic fusion bead preparation machine. The pressed powder pellets were prepared by using a solution of n-butyl methacrylate in acetone as binder and they were formed in a CASMON hydraulic press.

\subsubsection{Mineralogical analysis}

The mineralogical composition was determined out by X-ray diffraction (Brindley et al., 1984; Klein et al., 1985). The diffractograms of the powder samples were obtained using a Bruker D8 Advance theta-theta diffractometer model with copper radiation $(\lambda=1.54183 \AA \mathrm{Ka})$. The equipment has a secondary monochromator and measurements were made with a Bruker VANTEC solid state detector. The experimental measurement conditions were 5 to $90^{\circ}(2 \theta)$ with a step size of 0.015 and $1.2 \mathrm{~s} / \mathrm{step}$. The crystalline phases were quantified by the Rietveld method (Zevin et al., 1995). All diffractograms were treated with TOPAS program version 4.2 (Bruker).

The crystalline phases of the powder samples were identified from the positions and intensities of the diffracted peaks using the ICDD database powder diffraction files (http://www.icdd.com/, 2014). The solved structures used to carry out the quantification in the study were obtained from the ICDD PDF 4 database of inorganic structures. The amorphous phase was determined by adding a known mass concentration of fluorite as internal standard to the powdered samples. The difference between the weight percentage of the fluorite addition and quantity determined by the Rietveld method allowed estimation of the amorphous phase. 
To determine the mineralogical phases present in the fired ceramic compositions, an unfired test piece of each type of composition, $40 \mathrm{~mm}$ in diameter and $6 \mathrm{~mm}$ thick, was formed by uniaxial pressure in a laboratory press. The average dry bulk density of these pieces was $2000 \pm 0.005 \mathrm{~g} / \mathrm{cm}^{3}$. Each test piece was then fired to the composition's peak temperature, detailed in table 1 . The heating rate was 5 ${ }^{\circ} \mathrm{C} / \min$.

For X-ray diffraction analysis, between 10 and $30 \mathrm{~g}$ of each unfired composition was dried in an oven at $110{ }^{\circ} \mathrm{C}$ for at least 2 hours. The same quantity of fired sample was also weighed. Each unfired and fired composition was ground in a tungsten carbide ring mill to a particle size below $100 \mu \mathrm{m}$.

\subsubsection{Material characterisation results}

The seven studied traditional ceramic products had different mineralogical compositions, which determined the physico-chemical transformations that developed during the firing cycle and, consequently, product end properties. The chemical and mineralogical composition of the seven test compositions are detailed in table 2 and table 3, respectively. The sulphur content was negligible in all compositions.

Table 2. Chemical analysis and loss on ignition (LOI) (\%) of the seven test compositions (\% by weight).

\begin{tabular}{|c|c|c|c|c|c|c|c|}
\cline { 2 - 8 } \multicolumn{1}{c|}{} & \multicolumn{7}{c|}{ Composition } \\
\hline Oxides & RBT & PCT & RWT & WWT & WBR & RFT & PTW \\
\hline $\mathrm{SiO}_{2}$ & 72.02 & 73.84 & 65.63 & 72.12 & 55.74 & 63.54 & 67.05 \\
\hline $\mathrm{Al}_{2} \mathrm{O}_{3}$ & 16.91 & 19.59 & 17.21 & 16.46 & 19.99 & 12.44 & 29.84 \\
\hline $\mathrm{Fe}_{2} \mathrm{O}_{3}$ & 3.79 & -- & 4.11 & 1.24 & 1.98 & -- & 0.40 \\
\hline $\mathrm{TiO}_{2}$ & -- & -- & -- & 0.71 & -- & -- & 0.12 \\
\hline $\mathrm{CaO}^{n}$ & 1.50 & 0.40 & 7.10 & 7.15 & 12.62 & 18.66 & 0.18 \\
\hline $\mathrm{MgO}$ & 1.30 & --- & 1.63 & 0.23 & 4.62 & 0.96 & 0.15 \\
\hline $\mathrm{K}_{2} \mathrm{O}$ & 2.36 & 0.97 & 2.72 & 1.95 & 3.70 & 2.25 & 0.80 \\
\hline $\mathrm{Na} 2 \mathrm{O}$ & 2.13 & 5.20 & 1.61 & 0.15 & 1.36 & 2.15 & 1.46 \\
\hline $\mathrm{LOI}$ & 5.21 & 3.88 & 9.11 & 9.10 & 13.44 & 13.55 & 8.60 \\
\hline $\mathrm{Total}$ & 100 & 100 & 100 & 100 & 100 & 100 & 100 \\
\hline
\end{tabular}


Table 3. Mineralogical analysis and organic matter content of the seven test compositions ( $\%$ by weight).

\begin{tabular}{|c|c|c|c|c|c|c|c|c|}
\hline & \multirow[b]{3}{*}{ Crystalline phases } & & & & & & & \\
\hline & & \multicolumn{7}{|c|}{ Composition } \\
\hline & & RBT & PCT & RWT & WWT & WBR & RFT & PTW \\
\hline \multirow{4}{*}{ Clay minerals } & Kaolinite & $15 \pm 2$ & $19 \pm 2$ & $13 \pm 2$ & $18 \pm 2$ & $6 \pm 2$ & $4 \pm 2$ & $50 \pm 2$ \\
\hline & Illite/Muscovite mica & $19 \pm 2$ & $8 \pm 2$ & $21 \pm 2$ & $13 \pm 2$ & $23 \pm 2$ & $13 \pm 2$ & $10 \pm 2$ \\
\hline & Chlorite & $4 \pm 1$ & -- & $5 \pm 1$ & -- & $3 \pm 1$ & -- & -- \\
\hline & Paragonite & -- & -- & -- & -- & $6 \pm 1$ & -- & -- \\
\hline \multirow{2}{*}{ Carbonates } & Calcite & $2 \pm 1$ & -- & $11 \pm 1$ & $11 \pm 1$ & $10 \pm 1$ & $21 \pm 1$ & -- \\
\hline & Dolomite & $1 \pm 0.5$ & -- & $1 \pm 0.5$ & -- & $12 \pm 1$ & $3 \pm 1$ & -- \\
\hline \multirow{2}{*}{ Feldspars } & Potassium feldspar & $12 \pm 1$ & $6 \pm 1$ & $8 \pm 0.5$ & $7 \pm 1$ & $3 \pm 1$ & $6 \pm 1$ & $4 \pm 1$ \\
\hline & Albite & -- & $36 \pm 1$ & $1 \pm 0.5$ & -- & -- & $4 \pm 1$ & $6 \pm 1$ \\
\hline \multirow{2}{*}{ Oxides } & Quartz & $44 \pm 3$ & $31 \pm 3$ & $37 \pm 3$ & $51 \pm 3$ & $22 \pm 3$ & $29 \pm 3$ & $30 \pm 3$ \\
\hline & Haematite & $3 \pm 0.5$ & -- & $3 \pm 0.5$ & -- & $1 \pm 0.5$ & -- & -- \\
\hline Amorphous phase & - & -- & -- & -- & -- & $13 \pm 4$ & $20 \pm 4$ & -- \\
\hline \multirow{4}{*}{ Organic matter } & Biomass (olive pit) & -- & -- & -- & -- & $0.7 \pm 0.05$ & -- & -- \\
\hline & Polyvinyl alcohol (PVA) & -- & -- & -- & -- & -- & -- & $0.61 \pm 0.05$ \\
\hline & Polyvinyl glycol (PEG) & -- & -- & -- & -- & -- & -- & $0.20 \pm 0.05$ \\
\hline & Total & 100 & 100 & 100 & 100 & 100 & 100 & 100.81 \\
\hline
\end{tabular}

The firing behaviour of the bodies differed as a function of the composition, formulated to obtain the targeted end properties (porosity, mechanical strength, etc.) (Venturelli et al., 2007). Compositions RBT and PCT, used to manufacture red-body stoneware tile and porcelain tile, respectively, as well as the porcelain tableware composition (PTW), formed liquid phase at about $900{ }^{\circ} \mathrm{C}$, causing body porosity progressively to decrease as the temperature rose (Orts et al., 1993). On the other hand, compositions RWT, WWT, WBR, and RFT exhibited quite a high, steady porosity in the range of test temperatures, owing to the crystallisation of calcium silicates and aluminosilicates (gehlenite, anorthite, and wollastonite) from the reaction of $\mathrm{CaO}$, stemming from calcite and dolomite decomposition, with $\mathrm{Al}_{2} \mathrm{O}_{3}$ and $\mathrm{SiO}_{2}$ from clay mineral dehydroxylation (Cultrone et al., 2001; González-García et al., 1990; Peters et al., 1978; Riccardi et al., 1999). The mineralogical composition of the fired samples is detailed in table 4. 
Table 4. Mineralogical composition of the fired compositions ( $\%$ by weight).

\begin{tabular}{|c|c|c|c|c|c|c|c|}
\cline { 2 - 8 } \multicolumn{1}{c|}{} & \multicolumn{7}{c|}{ Composition } \\
\hline Crystalline phases & RBT & PCT & RWT & WWT & WBR & RFT & PTW \\
\hline Quartz & $35 \pm 3$ & $24 \pm 3$ & $28 \pm 3$ & $41 \pm 3$ & $19 \pm 3$ & $25 \pm 3$ & $30 \pm 3$ \\
\hline Haematite & $3 \pm 0.5$ & -- & $2 \pm 0.5$ & -- & $1 \pm 0.5$ & -- & -- \\
\hline Anorthite & -- & -- & $26 \pm 2$ & $18 \pm 2$ & -- & -- & -- \\
\hline Wollastonite & -- & -- & -- & $3 \pm 1$ & -- & $5 \pm 1$ & -- \\
\hline Enstatite & -- & -- & $1 \pm 0.5$ & -- & -- & -- & -- \\
\hline Diopside & -- & -- & $4 \pm 0.5$ & -- & $4 \pm 0.5$ & $4 \pm 0.5$ & -- \\
\hline Gehlenite & -- & -- & -- & $1 \pm 0.5$ & & $6 \pm 0.5$ & -- \\
\hline Mullite & $9 \pm 1$ & $8 \pm 1$ & -- & $4 \pm 1$ & & -- & -- \\
\hline Potassium feldspar & $6 \pm 0.5$ & -- & -- & -- & $3 \pm 0.5$ & $6 \pm 0.5$ & $4 \pm 0.5$ \\
\hline Albite & -- & $6 \pm 0.5$ & -- & -- & & $3 \pm 0.5$ & $6 \pm 0.5$ \\
\hline Illite/Muscovite mica & -- & -- & -- & -- & $7 \pm 0.5$ & -- & -- \\
\hline Akermanite & -- & -- & -- & -- & $5 \pm 0.5$ & -- & -- \\
\hline Periclase & -- & -- & -- & -- & $1 \pm 0.5$ & -- & -- \\
\hline Amorphous phase & $47 \pm 4$ & $62 \pm 4$ & $39 \pm 4$ & $33 \pm 4$ & $60 \pm 4$ & $51 \pm 4$ & $60 \pm 4$ \\
\hline Total & 100 & 100 & 100 & 100 & 100 & 100 & 100 \\
\hline
\end{tabular}

\subsection{Energy required to fire the studied ceramic materials}

All the thermal energy that reaches a ceramic composition is used in raising its temperature and in developing the different physico-chemical transformations of the material in the firing process. This heat can be calculated from the following equation, in which the first term of the equation corresponds to the energy needed to raise the composition temperature, and the second term is the total enthalpy of the chemical reactions.

Equation $1 \quad Q_{C}=\int_{T_{i}}^{T_{f}} m_{c} \cdot C p_{c}+\Delta H_{R}$

where:

- $\quad \mathrm{m}_{\mathrm{c}}$ is the mass flow $(\mathrm{kg} / \mathrm{s})$ (in dynamic systems) or mass $(\mathrm{kg})$ (in static systems) of the ceramic composition that is conveyed through or is stacked in the kiln, respectively.

- $\quad C p_{c}$ is the specific heat of the ceramic composition $(\mathrm{J} / \mathrm{kg} \mathrm{K})$, which varies as a function of the composition and temperature at each moment. 
- $\quad T_{f}$ and $T_{i}$ are the peak firing temperature and the kiln entrance temperature $(K)$, respectively.

- $\Delta \mathrm{H}_{\mathrm{R}}$ is the enthalpy of the physico-chemical reactions involved $(\mathrm{kJ} / \mathrm{kg})$.

In this study, the enthalpy of reaction was determined in two ways: by an experimental method (method 1) using differential scanning calorimetry (DSC) and by an analytical method (method 2), performing a calculation based on the mineralogical composition of the ceramic body. The information required to calculate the heat of reaction in each method is summarised in table 5.

Table 5. Information required for the two methods.

\begin{tabular}{|c|c|c|c|}
\hline Method & Information required & Test or source & Designation \\
\hline \multirow{2}{*}{$\mathbf{1}$} & Direct method (direct obtainment of the heat of reaction) & DSC & $\begin{array}{c}\text { Experimental } \\
\text { method }\end{array}$ \\
\hline \multirow{2}{*}{$\mathbf{2}$} & $\begin{array}{c}\text { Determination and quantification of the mineralogical } \\
\text { composition of the (unfired and fired) ceramic composition }\end{array}$ & X-ray diffraction & $\begin{array}{c}\text { Analytical } \\
\text { method }\end{array}$ \\
\cline { 2 - 4 } & Enthalpies of formation of the compositional constituents & $\begin{array}{c}\text { - Thermodynamic tables } \\
\text { - Literature sources }\end{array}$ & \\
\hline
\end{tabular}

The information in table 5 is set out in further detail below.

\subsubsection{Experimental method}

The enthalpy of reaction of the composition was determined in the laboratory using a Netzsch model STA 449C DSC instrument. The instrument enables a product's heat per unit mass in the firing process to be quantified throughout a thermal cycle (Hatakeyama et al., 2000) and allows measurement up to temperatures of $1350{ }^{\circ} \mathrm{C}$, with an error of $5-10 \%$. The instrument was coupled to a thermogravimetric analysis unit, thus simultaneously recording mass loss as a function of temperature. A description follows of the method used to determine the heat of reaction.

A sample of the composition to be analysed and a standard sample were placed in a kiln and subjected to a controlled thermal cycle. The standard was a sapphire disk of known thickness and calorific capacity, which underwent no significant physico-chemical transformation from an energy viewpoint in the test temperature range. 
The sample to be analysed needed to be in the form of a homogeneous fine powder with a particle size below $100 \mu \mathrm{m}$. To obtain the test powders, the bulk samples were dried in an oven at $110{ }^{\circ} \mathrm{C}$ for at least 2 hours and then ground in a tungsten carbide ring mill. The thermal treatments were carried out in platinum crucibles with their respective covers, in a dynamic atmosphere of air and protective argon gas.

In each DSC test, the temperature was raised from ambient temperature to the composition peak firing temperature, using a 4-step procedure: 1) from room temperature to $\left.40{ }^{\circ} \mathrm{C}\left(v=3{ }^{\circ} \mathrm{C} / \mathrm{min}\right) ; 2\right)$ isotherm at $40{ }^{\circ} \mathrm{C}$ (10 minutes); 3 ) from $40{ }^{\circ} \mathrm{C}$ to the peak temperature for each composition detailed in table 1 ( $v=5$ $\left.{ }^{\circ} \mathrm{C} / \mathrm{min}.\right) ; 4$ ) isotherm at peak temperature (5 minutes).

The mass and temperature of the sample and of the standard, as well as the required heat input to the sample to keep it at the same temperature as the standard, were determined during the thermal cycle. This information, together with a previous calibration that provided the coefficients of heat transmission in the firing chamber, enabled the heat flux to the sample and from the sample to the kiln to be determined. The test yielded the following information:

- Composition calorific capacity as a function of temperature. Integrating this curve in each temperature range and multiplying by the test mass enabled the heat of reaction in each range to be obtained.

- Composition heat flux as a function of temperature. This curve showed the heat exchange of the sample with the ambient. That is, whether the chemical reactions that took place were endothermic or exothermic.

- Composition mass loss as a function of temperature.

The joint interpretation of the three curves allowed the chemical reactions of the composition during the thermal cycle, the mass loss associated with each reaction, the heat released or absorbed, as well as the approximate start and end of each reaction, to be identified. The sum of the heat of reaction of the identified chemical reactions provided the overall reaction enthalpy $\left(\Delta \mathrm{H}_{\mathrm{R}}\right)$. 


\subsubsection{Analytical method}

The heat of reaction was calculated by the analytical method according to the following steps:

1. Determination and quantification of the mineralogical phases present in the starting ceramic composition and in the final fired piece.

2. Identification of the most significant reactions during thermal treatment of the composition from an energy viewpoint. These reactions are shown in table 6 .

3. Calculation of the enthalpy of reaction of each transformation from the enthalpy of formation of its products and reagents. These values were either drawn from thermodynamic databases (Holland and Powell, 2011) or, when unavailable, from the literature (Hirono et al., 2011; Ratzenberger et al., 1993; Vogt et al., 2004 and 2012).

4. Calculation, from the fractions by weight of each compositional constituent, of the energy that each reaction contributed. The sum of these contributions yielded the total heat of reaction of the composition.

After the mineralogical phases in the unfired and fired compositions had been determined and quantified, taking into account the physico-chemical reactions found in the literature review (summarised in table 6), the most significant foreseeable reactions during firing, from an energy viewpoint, were respectively assigned to each composition. 
Table 6. Reactions considered during thermal treatment and enthalpies of reaction calculated from the enthalpies of formation.

\begin{tabular}{|c|c|c|c|c|}
\hline \multirow{3}{*}{$\begin{array}{c}\begin{array}{c}\text { Mineralogical phases } \\
\text { and components }\end{array} \\
\text { Free water }\end{array}$} & \multirow{2}{*}{\multicolumn{2}{|c|}{ Reactions }} & \multicolumn{2}{|c|}{ Enthalpy } \\
\hline & & & \multirow{2}{*}{$\begin{array}{c}\text { Symbol } \\
\Delta h_{1}\end{array}$} & \multirow{2}{*}{$\begin{array}{c}\text { Value }(\mathbf{k J} / \mathbf{k g} \\
\text { component i) } \\
2500\end{array}$} \\
\hline & $\mathrm{r}_{1}$ & $\mathrm{H}_{2} \mathrm{O}(\mathrm{l}) \rightarrow \mathrm{H}_{2} \mathrm{O}(\mathrm{g})$ & & \\
\hline \multicolumn{5}{|c|}{ Clay mineral dehydroxylation } \\
\hline Kaolinite & $\mathrm{r}_{2}$ & $\mathrm{Al}_{2} \mathrm{O}_{3} \cdot 2 \mathrm{SiO}_{2} \cdot 2 \mathrm{H}_{2} \mathrm{O}(\mathrm{s}) \rightarrow \mathrm{Al}_{2} \mathrm{O}_{3} 2 \mathrm{SiO}_{2}(\mathrm{~s})+2 \mathrm{H}_{2} \mathrm{O}(\mathrm{g})$ & $\Delta h_{2}$ & $1158(*)$ \\
\hline Illite/Muscovite mica & $\mathrm{r}_{3}$ & $\begin{array}{c}(1 / 2) \mathrm{K}_{2} \mathrm{O} \cdot(3 / 2) \mathrm{Al}_{2} \mathrm{O}_{3} \cdot 3 \mathrm{SiO}_{2} \mathrm{H}_{2} \mathrm{O}(\mathrm{s}) \rightarrow \\
(1 / 2) \mathrm{K}_{2} \mathrm{O} \cdot(1 / 2) \mathrm{Al}_{2} \mathrm{O}_{3} \cdot 3 \mathrm{SiO}_{2}(\mathrm{~s})+\mathrm{Al}_{2} \mathrm{O}_{3}(\mathrm{~s})+\mathrm{H}_{2} \mathrm{O}(\mathrm{g})\end{array}$ & $\Delta h_{3}$ & $374(*)$ \\
\hline Chlorite & $\mathrm{r}_{4}$ & $\begin{array}{c}(\mathrm{Mg}, \mathrm{Fe}, \mathrm{Al})_{6}(\mathrm{Si}, \mathrm{Al})_{4} \mathrm{O}_{10}(\mathrm{OH})_{8} \rightarrow(\mathrm{Mg}, \mathrm{Fe}, \mathrm{Al})_{6}(\mathrm{Si}, \mathrm{Al})_{4} \mathrm{O}_{6}(\mathrm{~s}) \\
+4 \mathrm{H}_{2} \mathrm{O}(\mathrm{g})\end{array}$ & $\Delta h_{4}$ & $323(*)$ \\
\hline Paragonite & $\mathrm{r}_{5}$ & $\begin{array}{c}(1 / 2) \mathrm{Na}_{2} \mathrm{O} \cdot(3 / 2) \mathrm{Al}_{2} \mathrm{O}_{3} \cdot 3 \mathrm{SiO}_{2} \cdot \mathrm{H}_{2} \mathrm{O}(\mathrm{s}) \rightarrow \\
(1 / 2) \mathrm{Na}_{2} \mathrm{O} \cdot(1 / 2) \mathrm{Al}_{2} \mathrm{O}_{3} \cdot 3 \mathrm{SiO}_{2}+\mathrm{Al}_{2} \mathrm{O}_{3}(\mathrm{~s})+\mathrm{H}_{2} \mathrm{O}(\mathrm{g})\end{array}$ & $\Delta h_{5}$ & 236 \\
\hline \multicolumn{5}{|c|}{ Quartz inversion } \\
\hline Quartz inversion & $\mathrm{r}_{6}$ & $\alpha-\mathrm{SiO}_{2}(\mathrm{~s}) \rightarrow \beta-\mathrm{SiO}_{2}(\mathrm{~s})$ & $\Delta h_{6}$ & 11.7 \\
\hline \multicolumn{5}{|c|}{ Carbonate decomposition } \\
\hline Calcite & $\mathrm{r}_{7}$ & $\mathrm{CaCO}_{3}(\mathrm{~s}) \rightarrow \mathrm{CaO}(\mathrm{s})+\mathrm{CO}_{2}(\mathrm{~g})$ & $\Delta h_{7}$ & 1796 \\
\hline Dolomite & $\mathrm{r}_{8}$ & $\mathrm{CaMg}\left(\mathrm{CO}_{3}\right)_{2}(\mathrm{~s}) \rightarrow \mathrm{CaO}(\mathrm{s})+\mathrm{MgO}(\mathrm{s})+2 \mathrm{CO}_{2}(\mathrm{~g})$ & $\Delta h_{8}$ & 1646 \\
\hline \multicolumn{5}{|c|}{ Crystallisation of calcium phases - Formation of new crystalline phases } \\
\hline Anorthite & $r_{9}$ & $\mathrm{Al}_{2} \mathrm{O}_{3}(\mathrm{~s})+\mathrm{SiO}_{2}(\mathrm{~s})+\mathrm{CaOSiO}_{2}(\mathrm{~s}) \rightarrow \mathrm{CaO} \cdot \mathrm{Al}_{2} \mathrm{O}_{3} \cdot 2 \mathrm{SiO}_{2}(\mathrm{~s})$ & $\Delta h_{9}$ & -46 \\
\hline Wollastonite & $\mathrm{r}_{10}$ & $\mathrm{CaO}(\mathrm{s})+\mathrm{SiO}_{2}(\mathrm{~s}) \rightarrow \mathrm{CaO} \cdot \mathrm{SiO}_{2}(\mathrm{~s})$ & $\Delta h_{10}$ & -760 \\
\hline Enstatite & $r_{11}$ & $2 \mathrm{MgO}(\mathrm{s})+2 \mathrm{SiO}_{2}(\mathrm{~s}) \rightarrow 2 \mathrm{MgO} \cdot \mathrm{SiO}_{2}(\mathrm{~s})$ & $\Delta h_{11}$ & -655 \\
\hline Diopside & $\mathrm{r}_{12}$ & $\mathrm{CaO}(\mathrm{s})+\mathrm{MgO}(\mathrm{s})+2 \mathrm{SiO}_{2}(\mathrm{~s}) \rightarrow \mathrm{CaO} \cdot \mathrm{MgO} \cdot 2 \mathrm{SiO}_{2}(\mathrm{~s})$ & $\Delta h_{12}$ & -666 \\
\hline Akermanite & $r_{13}$ & $2 \mathrm{CaO}(\mathrm{s})+\mathrm{MgO}(\mathrm{s})+2 \mathrm{SiO}_{2}(\mathrm{~s}) \rightarrow 2 \mathrm{CaO} \cdot \mathrm{MgO} \cdot 2 \mathrm{SiO}_{2}(\mathrm{~s})$ & $\Delta h_{13}$ & -636 \\
\hline Gehlenite & $\mathrm{r}_{14}$ & $2 \mathrm{CaO}(\mathrm{s})+\mathrm{Al}_{2} \mathrm{O}_{3}(\mathrm{~s})+\mathrm{SiO}_{2}(\mathrm{~s}) \rightarrow 2 \mathrm{CaO} \cdot \mathrm{Al}_{2} \mathrm{O}_{3} \cdot \mathrm{SiO}_{2}(\mathrm{~s})$ & $\Delta h_{14}$ & -500 \\
\hline Mullite & $r_{15}$ & $\mathrm{Al}_{2} \mathrm{O}_{3} \cdot 2 \mathrm{SiO}_{2}(\mathrm{~s}) \rightarrow(1 / 3) 3 \mathrm{Al}_{2} \mathrm{O}_{3} \cdot 2 \mathrm{SiO}_{2}(\mathrm{~s})+(4 / 3) \mathrm{SiO}_{2}(\mathrm{~s})$ & $\Delta h_{15}$ & -280 \\
\hline \multicolumn{5}{|c|}{ Glassy phase formation by fusion of the crystalline phase } \\
\hline Potassium feldspar & $r_{16}$ & $\mathrm{~K}_{2} \mathrm{O} \cdot \mathrm{Al}_{2} \mathrm{O}_{3} \cdot 6 \mathrm{SiO}_{2}(\mathrm{~s}) \rightarrow \mathrm{K}_{2} \mathrm{O} \cdot \mathrm{Al}_{2} \mathrm{O}_{3} \cdot 6 \mathrm{SiO}_{2}(\mathrm{l})$ & $\Delta h_{16}$ & 207 \\
\hline Albite & $\mathrm{r}_{17}$ & $\mathrm{Na}_{2} \mathrm{O} \cdot \mathrm{Al}_{2} \mathrm{O}_{3} \cdot 6 \mathrm{SiO}_{2}(\mathrm{~s}) \rightarrow \mathrm{Na}_{2} \mathrm{O} \cdot \mathrm{Al}_{2} \mathrm{O}_{3} \cdot 6 \mathrm{SiO}_{2}(\mathrm{l})$ & $\Delta h_{17}$ & 226 \\
\hline
\end{tabular}

(*) When the enthalpy of formation of the minerals was unavailable, values from the literature were used (Hirono et al., 2011; Ratzenberger et al., 1993; Vogt et al., 2004 and 2012). 
This method also takes into account the crystallisation of calcium phases (exothermic process) and glassy phase formation in the sintering process (endothermic process). These processes are complex and, besides depending on the composition, they also depend on peak temperature and residence time at peak temperature. Owing to their complexity and relatively low energy value in the overall process, the calculation of the energy contribution of glassy phase fusion was limited to the energy calculation of the fusion of the fluxes, without taking into account the other compositional components in the glassy phase. However, in future studies it will be attempted to define these high-temperature processes more extensively in the calculation method.

According to the principles of thermodynamics, enthalpy is a function of state. Consequently, the standard enthalpy of reaction $\left(\Delta H_{R}^{0}\right)$ can be calculated by subtracting the sum of the standard enthalpies of formation of the reagents from the sum of the standard enthalpies of formation of the products, as shown in the following equation.

Equation $2 \quad \Delta H_{R}^{0}=\sum \Delta h_{f}^{0}($ products $)-\sum \Delta h_{f}^{0}($ reagents $)$

The values of the enthalpy of formation of the mineralogical phases used in the calculations were obtained from a thermodynamic database of minerals prepared by Holland and Powell Holland and Powell (2011), while the enthalpy of formation of metakaolinite was obtained from various literature sources (Schieltz et al., 1964; Vaughan, 1955). When the enthalpy of formation of the minerals was unavailable, such as that of the illite and chlorite clays, values from the literature were used (Hirono et al., 2011; Ratzenberger et al., 1993; Vogt et al., 2004 and 2012). The use of these enthalpy formation values, together with equation (2), enabled the enthalpies of reaction shown in table 6 to be calculated.

The values of the enthalpy of organic matter combustion used in the calculations were obtained from various literature sources (Walters et al., 2000; http://www.dow.com/, 2014). These values are shown in table 7. 
Table 7. Organic matter combustion considered during thermal treatment and combustion enthalpies.

\begin{tabular}{|c|c|c|}
\hline Organic matter & Organic matter combustion & $\begin{array}{c}\text { Value (kJ/kg } \\
\text { component i) }\end{array}$ \\
\hline $\begin{array}{c}\text { Biomass (olive pit known as } \\
\text { "orujillo") }\end{array}$ & $\mathrm{C}_{\mathrm{x}} \mathrm{H}_{\mathrm{y}} \mathrm{O}_{\mathrm{z}}(\mathrm{s})+\mathrm{O}_{2}(\mathrm{~g}) \rightarrow \mathrm{aCO}_{2}(\mathrm{~g})+\mathrm{bH}_{2} \mathrm{O}(\mathrm{g})$ & -16663 \\
\hline Polyvinyl alcohol PVA & $\begin{array}{c}\left(\mathrm{CH}_{2} \mathrm{CH}(\mathrm{OH})\right)_{\mathrm{n}}(\mathrm{l})+\mathrm{O}_{2}(\mathrm{~g}) \rightarrow \mathrm{xCO}_{2}(\mathrm{~g})+ \\
\mathrm{yH} \mathrm{H}_{2} \mathrm{O}(\mathrm{g})\end{array}$ & -21310 \\
\hline Polyethylene glycol PEG 200 & $\begin{array}{c}\mathrm{H}-\left(\mathrm{O}-\mathrm{CH}_{2} \mathrm{CH}_{2}\right)_{4}-\mathrm{OH}(\mathrm{l})+10 \mathrm{O}_{2}(\mathrm{~g}) \rightarrow 8 \mathrm{CO}_{2}(\mathrm{~g})+ \\
9 \mathrm{H}_{2} \mathrm{O}(\mathrm{g})\end{array}$ & -26753 \\
\hline
\end{tabular}

Once the enthalpies of reaction had been obtained from the enthalpies of formation of the components in each composition, the total enthalpy of reaction of the ceramic composition was calculated, this being the sum of the contribution of each reaction that developed.

The fractions by weight of each component in the composition enabled the energy that each reaction contributed to be calculated. The total enthalpy of reaction of the ceramic composition, applying the values shown in table 6 , was calculated from equation 3 :

Equation $3 \quad \Delta H_{R}=\sum m_{i} \cdot \Delta h_{i}$

where $\mathrm{m}_{\mathrm{i}}$ is key component mass $(\mathrm{kg})$ and $\Delta \mathrm{h}_{\mathrm{i}}$ its enthalpy of reaction $(\mathrm{kJ} / \mathrm{kg})$.

To apply the analytical method, the key component was considered to be the mineralogical phase identified in the mineralogical analysis of the starting mixture (reactions $r_{1}$ to $r_{8}$ ) or the new mineralogical phase that formed (reactions $r_{9}$ to $r_{15}$ ). In reactions $r_{16}$ and $r_{17}$, the component content was considered to be the per cent weight difference between the potassium feldspar or albite present in the starting and in the final mixture. A degree of conversion equal to unity was assumed for all reactions. 


\section{Results and discussion}

The heat of reaction required for the physico-chemical transformations of the seven test compositions was determined according to the two described methods. To perform the calculations, the compositions were assumed to be dry, as the tests were conducted using dry test pieces. The energy calculations for each studied composition are set out below, and the results obtained with the two methods are compared.

The physical and chemical transformations that developed during firing in the studied compositions were identified from the curves shown below, obtained by DSC analysis. The curves relate the calorific capacity of the material to the temperature, and the numbers identify the peaks observed. The transformations observed in the seven studied compositions, as well as the temperature range and energy exchanged in each transformation, are broken down in figures 2 to 8 . 


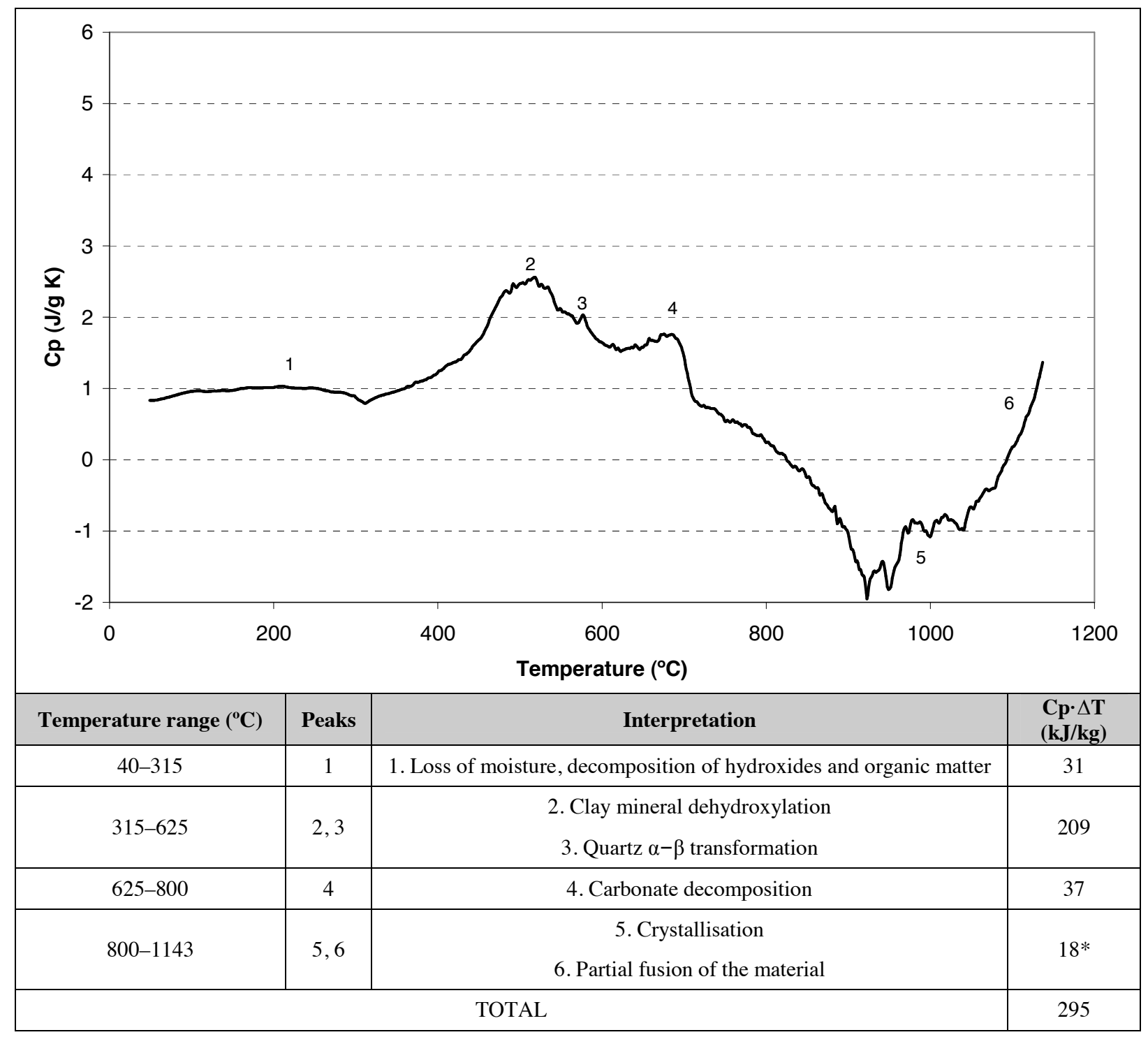

* Although crystallisation is an exothermic process and the fusion of the material is endothermic, the two processes have been grouped together and the total enthalpy is shown.

Figure 2. DSC curve and physico-chemical transformations identified in the RBT composition. 


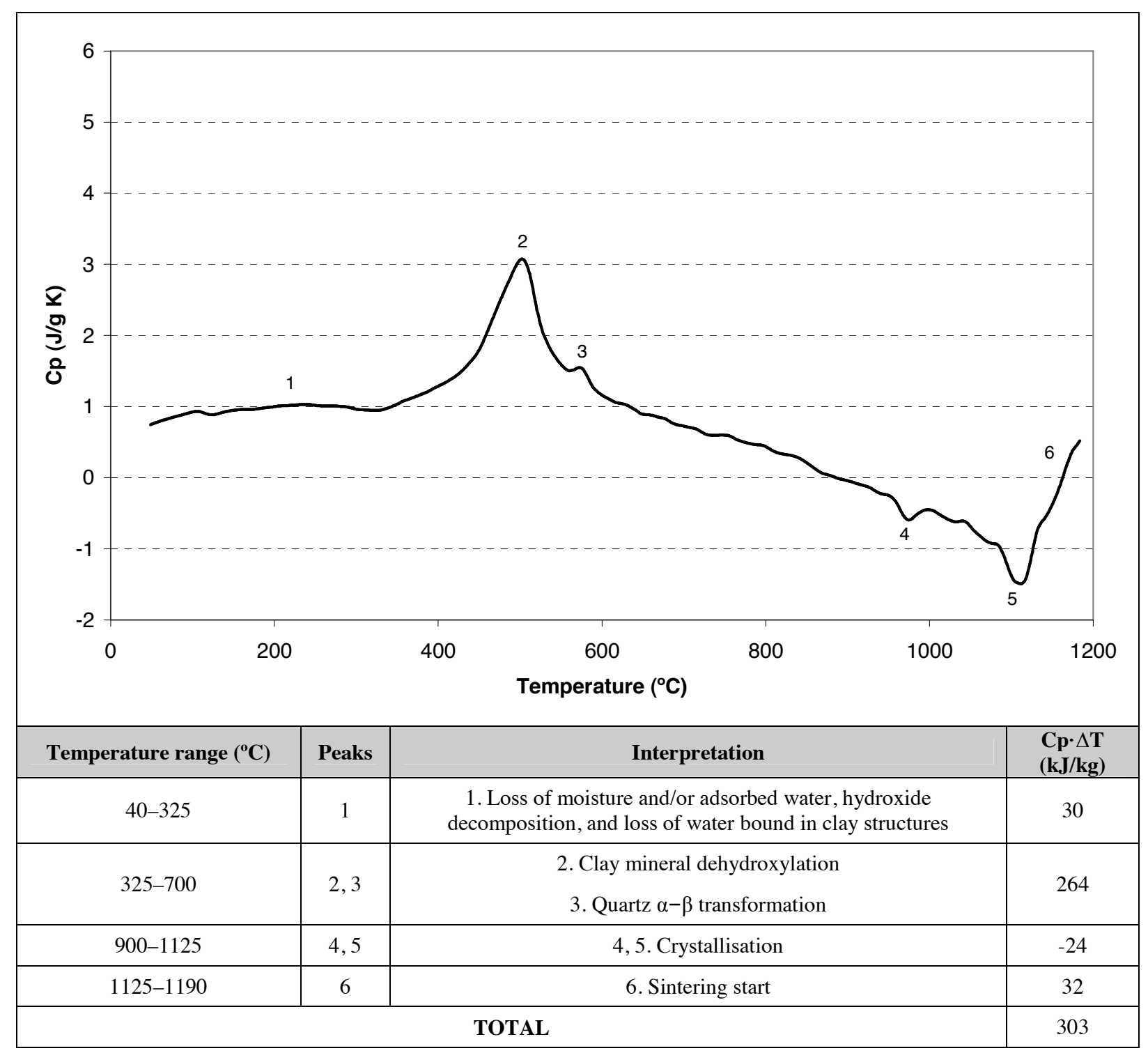

Figure 3. DSC curve and physico-chemical transformations identified in the PCT composition. 


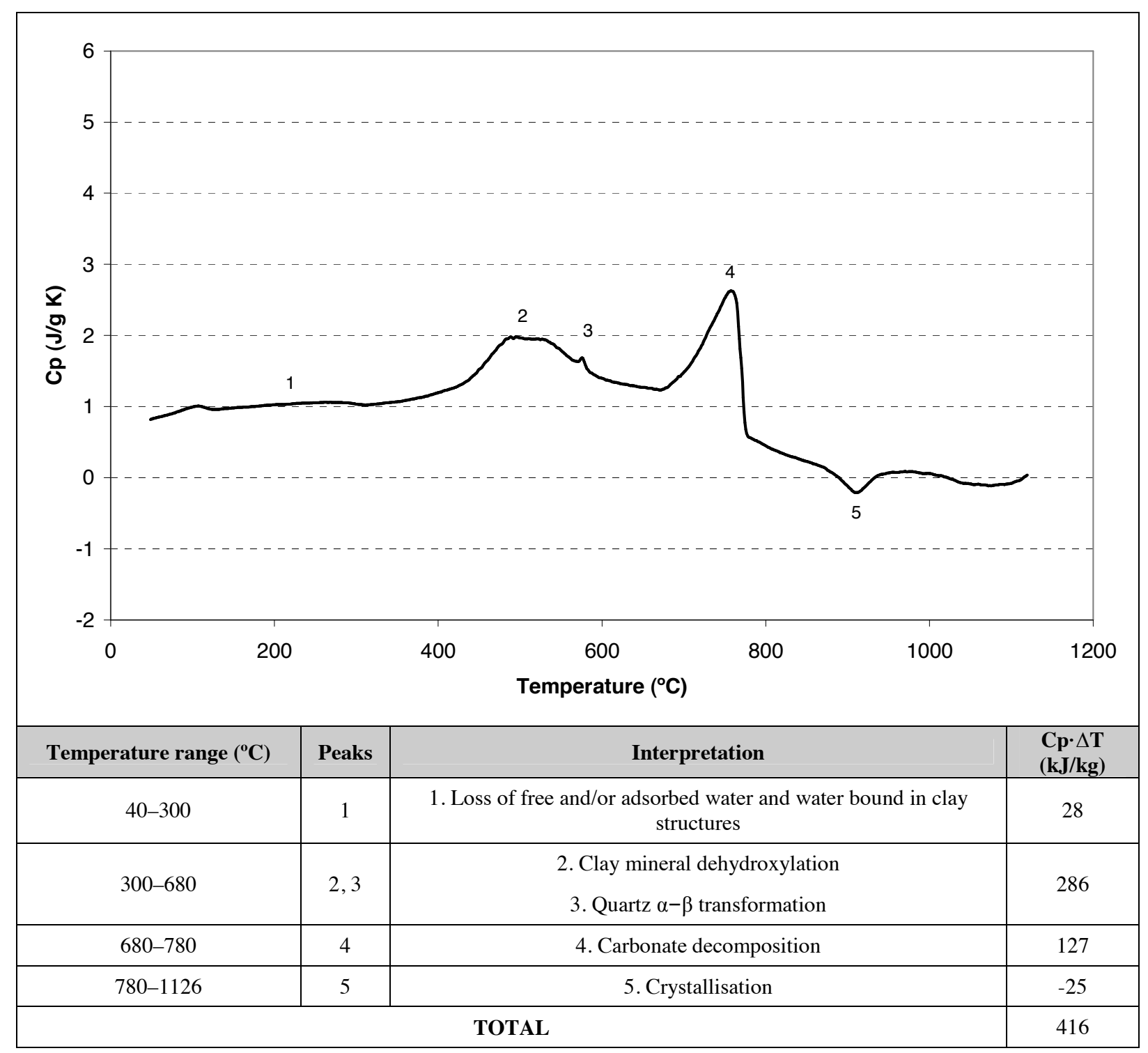

Figure 4. DSC curve and physico-chemical transformations identified in the RWT composition. 


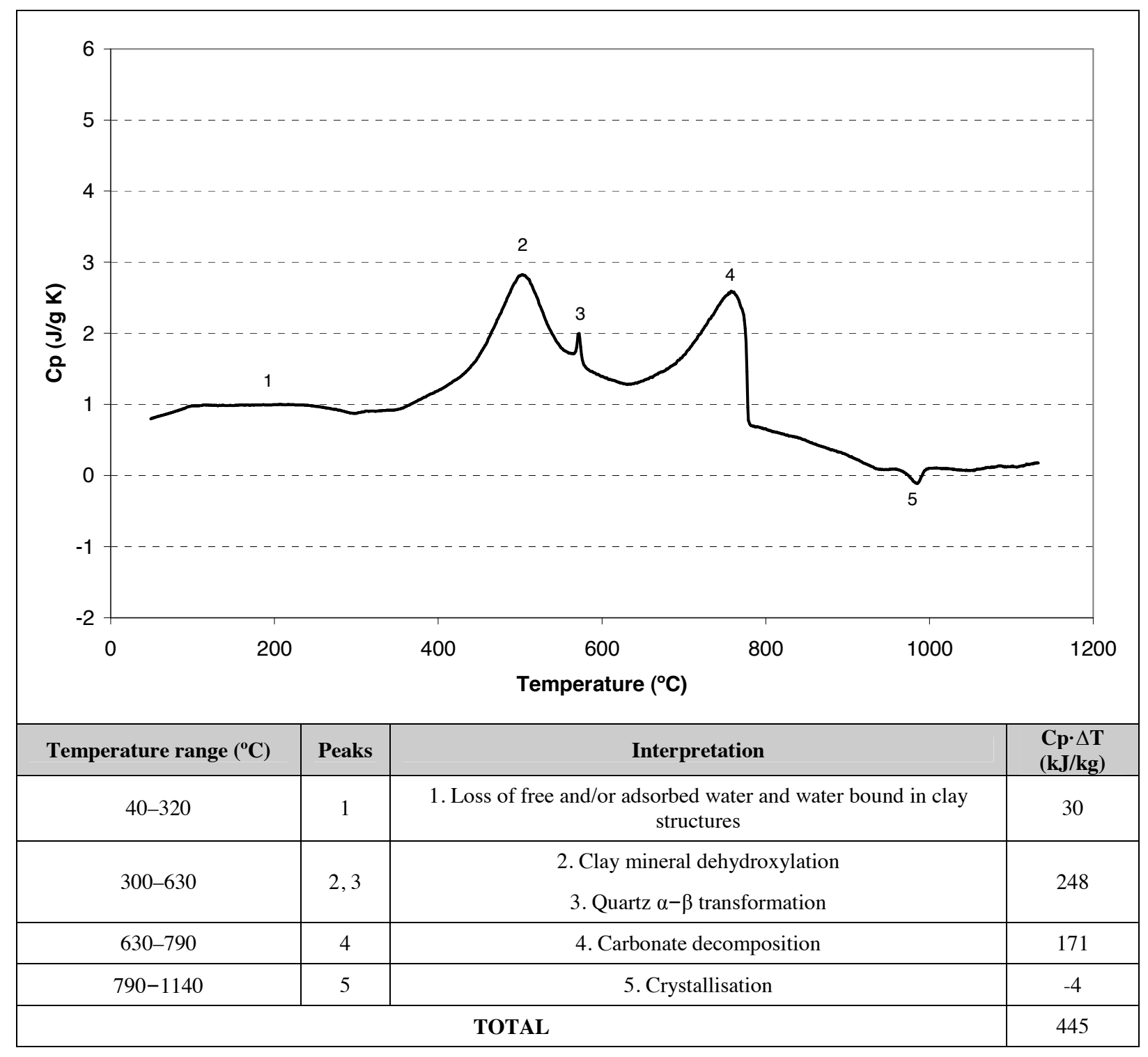

Figure 5. DSC curve and physico-chemical transformations identified in the WWT composition. 


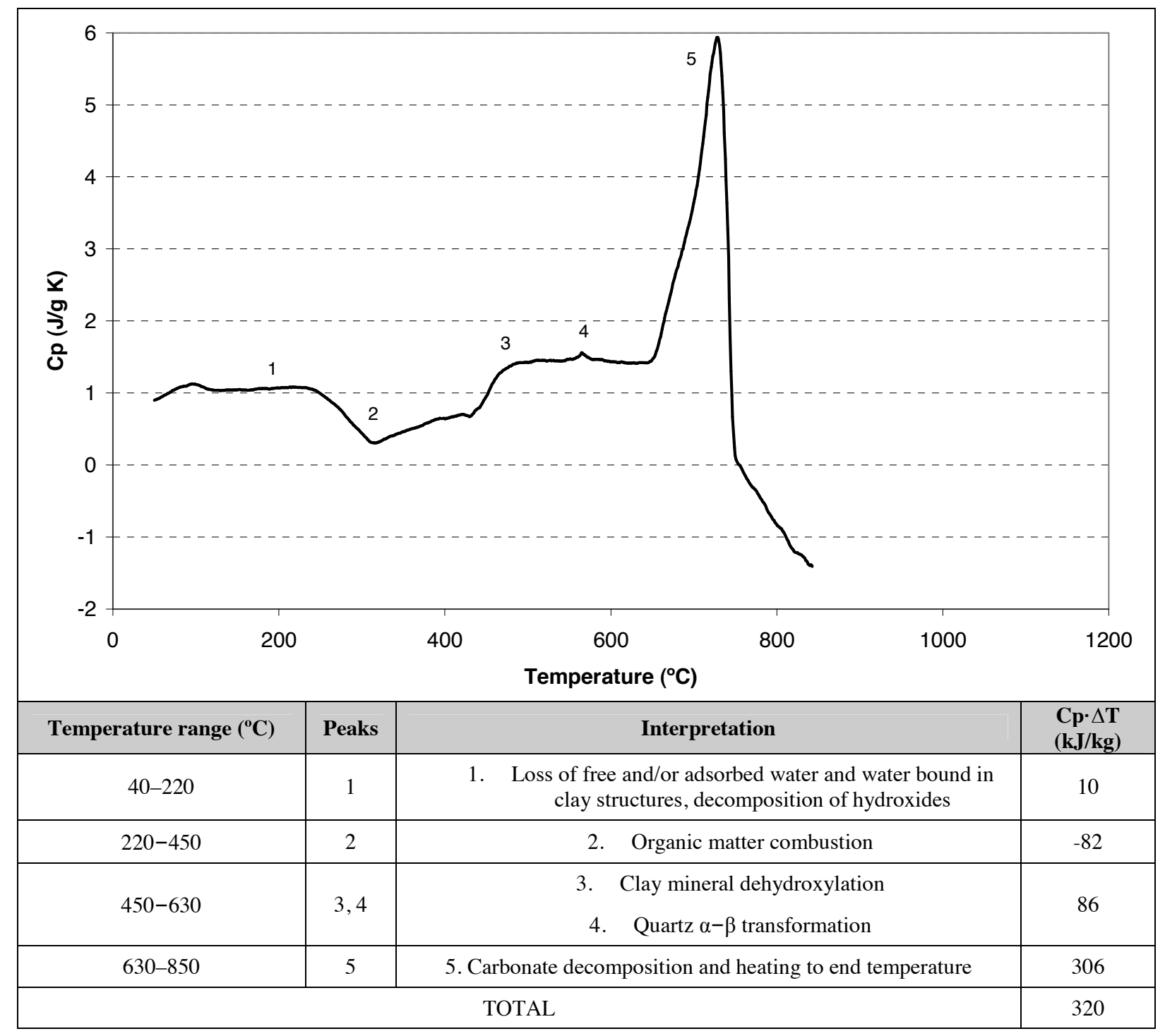

Figure 6. DSC curve and physico-chemical transformations identified in the WBR composition. 


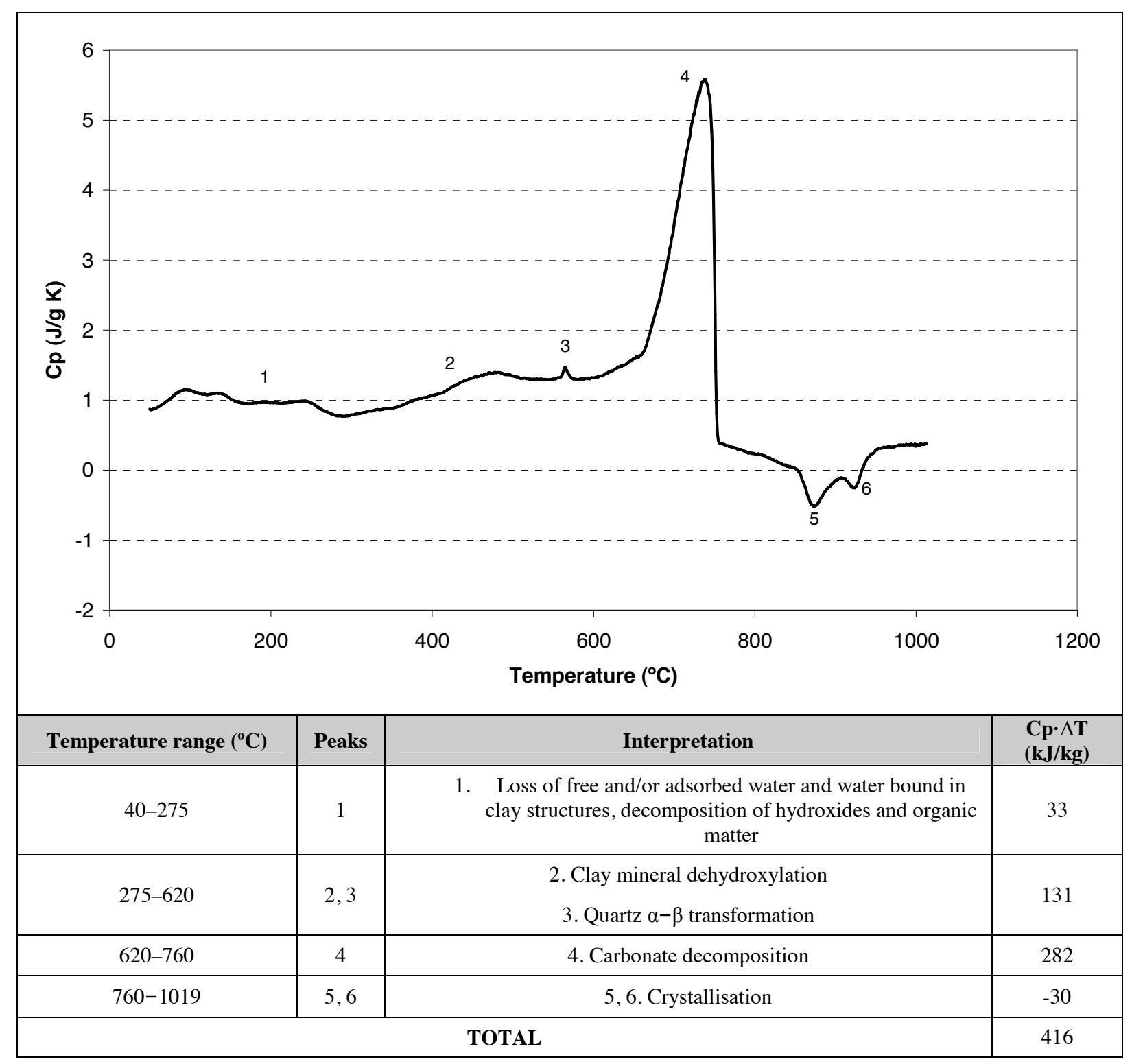

Figure 7. DSC curve and physico-chemical transformations identified in the RFT composition. 


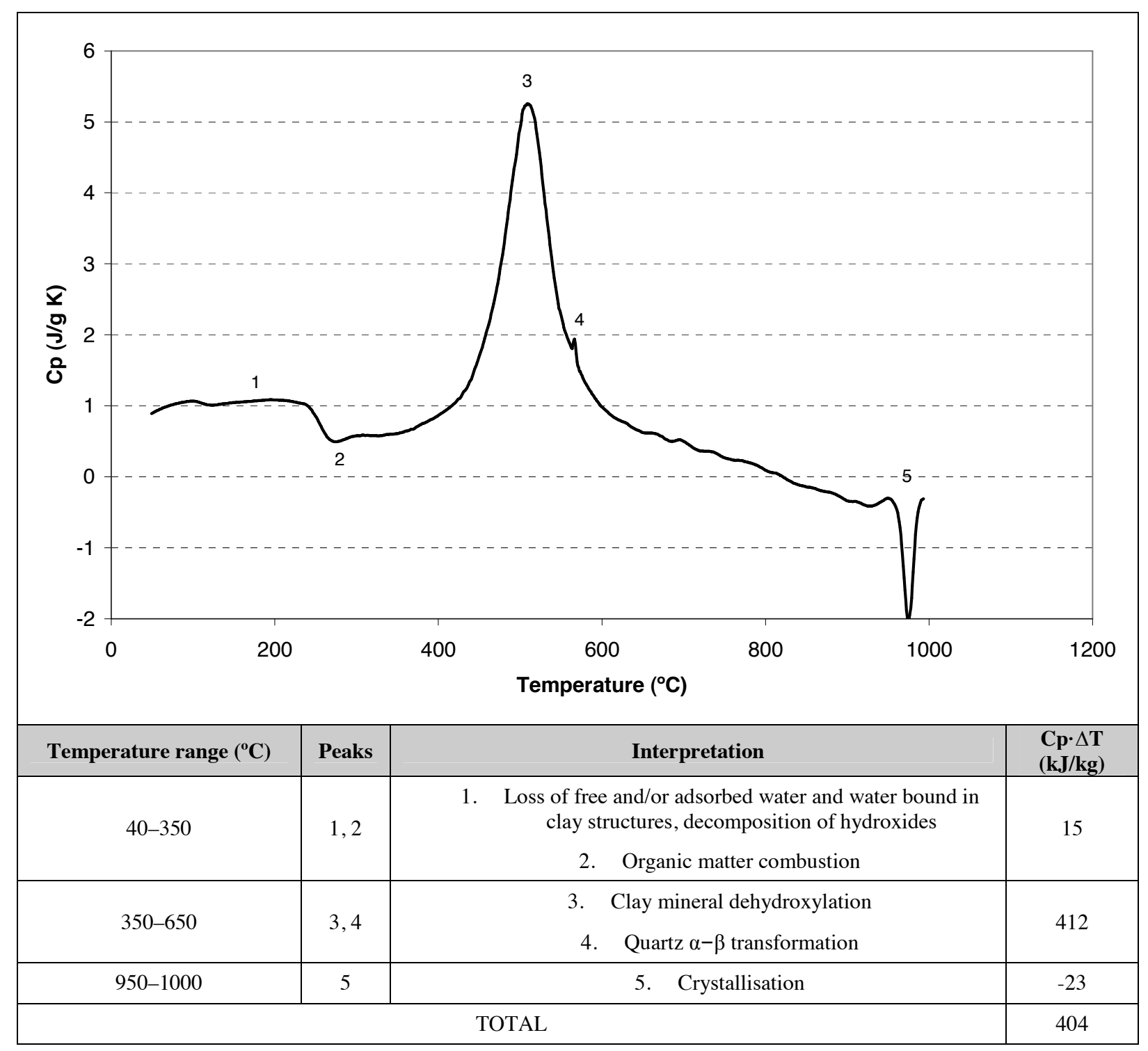

Figure 8. DSC curve and physico-chemical transformations identified in the PTW composition. 
Table 8 summarises the heat of reaction of the seven studied compositions determined by the experimental method, the values obtained using the proposed analytical method, and the difference in the results obtained by the two methods.

Table 8. Heat of reaction of the studied ceramic compositions.

\begin{tabular}{|c|c|c|c|c|}
\hline \multicolumn{2}{|c|}{ Composition } & \multicolumn{3}{|c|}{ Heat of reaction } \\
\cline { 3 - 5 } \multicolumn{2}{|c|}{} & $\begin{array}{c}\text { Experimental method } \\
(\mathbf{k J} / \mathbf{k g} \text { unfired tile })\end{array}$ & $\begin{array}{c}\text { Analytical method } \\
(\mathbf{k J} / \mathbf{k g} \text { unfired tile) }\end{array}$ & $\begin{array}{c}\text { Difference } \\
(\%)\end{array}$ \\
\hline Red-body stoneware tile & RBT & $295 \pm 30$ & $298 \pm 35$ & 1.0 \\
\hline Porcelain tile & PCT & $303 \pm 30$ & $320 \pm 25$ & 3.8 \\
\hline Red-body earthenware wall tile & RWT & $417 \pm 42$ & $433 \pm 35$ & 5.9 \\
\hline White-body earthenware wall tile & WWT & $444 \pm 44$ & $418 \pm 36$ & 6.5 \\
\hline White brick & WBR & $320 \pm 32$ & $341 \pm 42$ & 1.2 \\
\hline Roof tile & RFT & $416 \pm 42$ & $411 \pm 62$ & 6.6 \\
\hline
\end{tabular}

The following observations may be drawn from the results obtained in figures 2 to 8 and table 8 :

- The figures show that, in all compositions, several transformations took place in the material when the unfired products were heated from ambient temperature to about $800{ }^{\circ} \mathrm{C}$. The most important transformations were removal of free water, organic matter combustion, allotropic transformation of $\alpha$-quartz to $\beta$-quartz, loss of $\mathrm{OH}^{-}$groups in the clays, and carbonate decomposition when the composition contained carbonates.

- Raising the temperature from about $800{ }^{\circ} \mathrm{C}$ to the programmed peak temperature (between 850 ${ }^{\circ} \mathrm{C}$ and $1200{ }^{\circ} \mathrm{C}$, depending on the composition) caused the physico-chemical transformations to develop that determined end product properties and led to the most important dimensional changes (shrinkage) in the low porosity products (stoneware and porcelain ware) and to the formation of stable crystalline phases (calcium silicates) in the porous products (earthenware wall tiles and structural ceramics). 
- From an energy viewpoint, clay mineral dehydroxylation and carbonate decomposition were the principal endothermic reactions, while organic matter combustion was the major exothermic process. The total heat of reaction therefore depended mainly on these transformations.

- Table 8 shows that the difference between the heat of reaction values obtained by the analytical method and those obtained by the experimental method for all compositions was quite small. The greatest difference was observed with compositions WBR and PTW, though the value remained within the allowable experimental uncertainty. The values obtained by the analytical method thus exhibited good agreement with the experimental data.

- Composition organic matter content needed to be taken into account in evaluating the heat of reaction. In the PTW composition, for instance, the organic additives used as binder and plasticiser significantly modified the heat of reaction. It may further be noted that, in the WBR composition, the organic matter was specifically introduced as fuel to reduce kiln energy consumption.

- Comparison of the energy consumption per unit mass shows that the WWT, RWT and RFT compositions consumed the most energy, followed by the PTW composition, the former owing to their larger carbonate content and the latter to its high kaolinite content. Although the WBR composition had the highest carbonate content, its energy consumption was intermediate. This was presumably related to the added organic matter and relatively low firing temperature. The PCT and RBT compositions consumed less specific energy, mainly because of their low carbonate content. 


\subsection{Final comparative analysis}

The results of the two studied methods (table 8) have been plotted for visual comparison in figure 9, in which the enthalpies of reaction of the seven test compositions calculated by the analytical method are plotted versus their experimentally determined enthalpies of reaction.

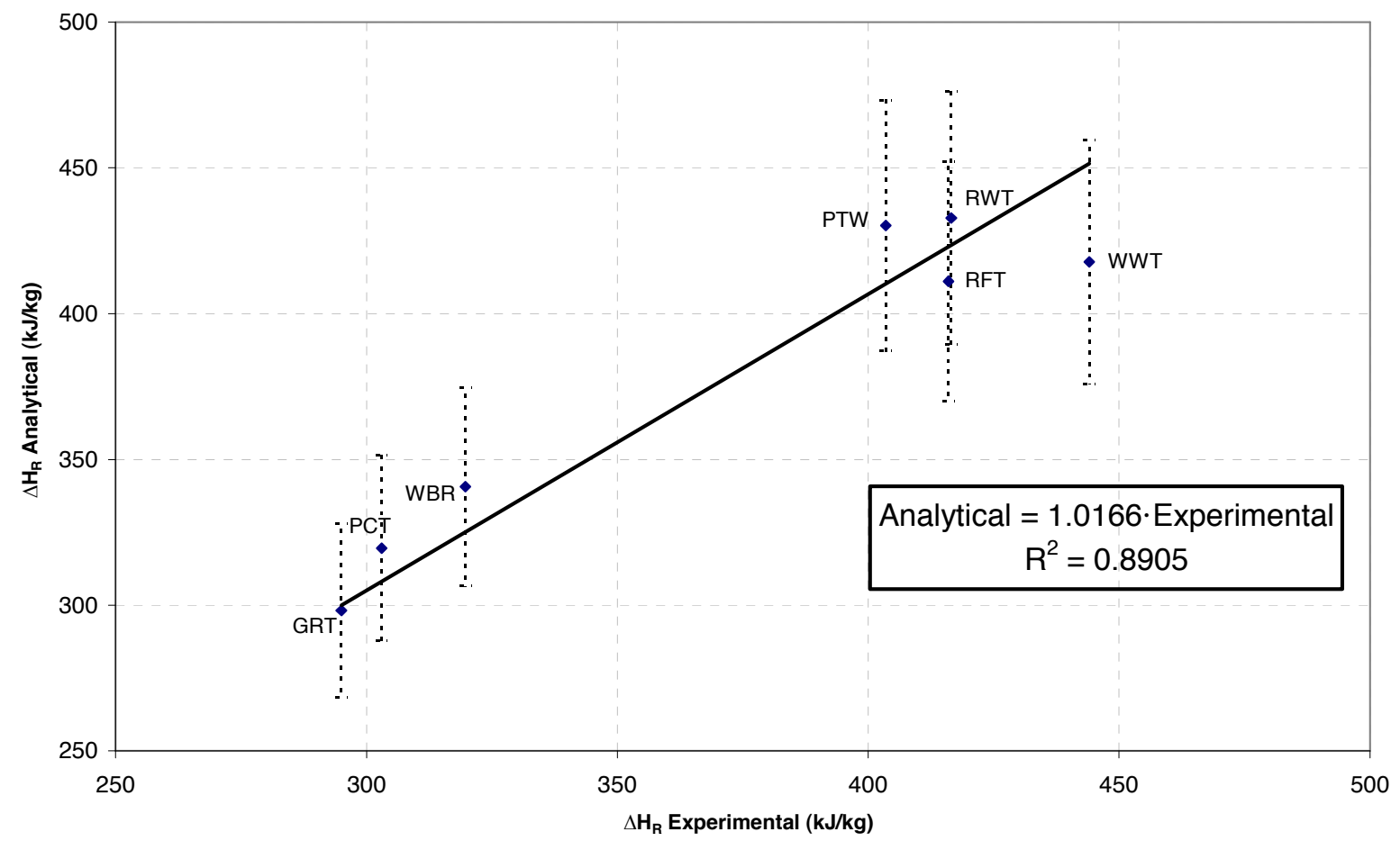

Figure 9. Experimental heat of reaction data versus the values calculated by the analytical method.

Good agreement between both sets of values can be observed, a linear relationship being obtained with a coefficient of regression of 0.8905 and slope close to 1 .

These results show that the proposed analytical method was appropriate for estimating the heat of transformation of the tested ceramic compositions, in the studied heat of reaction range. 


\section{Conclusions}

The following conclusions were drawn from the study:

o Differential scanning calorimetry (DSC) enabled the energy needed to fire seven typical body compositions used in traditional ceramic manufacture to be determined, the main transformations that took place during the firing cycle to be identified, and the energy involved in each transformation to be quantified.

- An analytical methodology was developed to determine the heat of reaction of traditional ceramic compositions, based on: 1) identification of the main physico-chemical transformations from the analysis of the unfired and fired mineral content; 2) the energy involved in these transformations, obtained from the literature and thermodynamic databases; and 3) the presence and type of organic matter. The results obtained exhibited good agreement with the experimental data obtained by DSC analysis.

o The results show that the heat of reaction in the studied traditional ceramic compositions is closely linked to the carbonate and clay mineral (especially kaolinite) content. On the other hand, it was verified that even low quantities of organic matter significantly influence the final heat of reaction, as organic matter combustion was highly exothermic. Consequently, the organic matter content in such compositions, including organic additives such as binders and plasticisers, need to be quantified in order to properly estimate the heat of reaction.

- The results obtained and the methodology developed in this study allow the energy involved in the firing of traditional ceramic compositions to be estimated. However, this estimation is not limited to the studied compositions, as other reactions can also be taken into account, depending on the raw materials composition. The developed analytical method can be used in simulation and optimisation studies on raw materials formulations, in industrial energy studies (e.g. in drawing up energy balances or estimating kiln efficiency), as well as in environmental studies (e.g. in life cycle assessments or in measuring carbon dioxide emissions or carbon footprints). 


\section{ACKNOWLEDGEMENTS}

This study was funded by the Valencian Institute of Business Competitiveness (IVACE) in the Competitiveness Improvement Programme through project IMAMCA/2014.

\section{References}

- Agrafiotis, C.; Tsoutsos, T. Energy saving technologies in the European ceramic sector: a systematic review. Appl. Thermal Eng. 21(12), 131-1249, 2001.

- Bernardo, E.; De Lazzari, M.; Colombo, P.; Saburit, A.; García-Ten, J. Lightweight porcelain stoneware by engineered $\mathrm{CeO}_{2}$ addition. Adv. Eng. Mater., 12(1-2), 65-70, 2010.

- Brindley, G.W.; Brown, G. Crystal structures of clay minerals and their X-ray identification. London: Mineralogical Society, 1984.

- Castelein, O., Soulestin, B., Bonnet, J.P., Blanchart, P. The influence of heating rate on the thermal behaviour and mullite formation from a kaolin raw material. Ceramics International, 27, pp. 517-522, 2001.

- Cultrone, G., Rodriguez-Navarro, C., Sebastian, E., Cazalla, O., De la Torre, M.J. Carbonate and silicate phase reactions during ceramic firing. European Journal of Mineralogy, 13 (2001), pp. 621-634

- Eliche, D., Martinez, C., Martínez, M.L, Cotes, M.T, Pérez, L., Cruz, N. et al. The use of different forms of waste in the manufacture of ceramic Tricks. Appl. clay sci., 52 (2011), pp. 270-276.

- European Commission, Reference Document on Best Available Techniques in the Ceramic Manufacturing Industry, 2007. Available at: http://eippcb.jrc.ec.europa.eu/reference/

- González-García, F., Romero-Acosta, V., García-Ramos, G., González-Rodríguez, M. Firing transformations of mixtures of clays containing illite, kaolinite and calcium carbonate used by ornamental tile industries. Appl. clay sci., 5 (4) (1990), pp. 361-375 
- Hatakeyama, T.; Zhenhai Liu (Eds.) (2000) Handbook of thermal analysis. Chichester: John Wiley \& sons.

- Hirono, T., Tanikawa, W. Implications of the thermal properties and kinetic parameters of dehydroxylation of mica minerals for fault weakening, frictional heating, and earthquake energetics. Earth and Planetary Science Letters, Volume 307, Issues 1-2, 1 July 2011, Pages $161-172$.

- Holland, T.J.B. \& Powell, R., 2011. An improved and extended internally consistent thermodynamic dataset for phases of petrological interest, involving a new equation of state for solids. Journal of Metamorphic Geology, 29, 333-383

- Klein, C. and Hurlbut, Jr., C. S. Manual of Mineralogy, after James D.Dana, $21^{\text {st }}$ edition, revised, John Wiley \& Sons, New York, 681 pp., 1985.

- M.D. Bovea, E. Díaz-Albo, A. Gallardo, F.J. Colomer, J. Serrano. Environmental performance of ceramic tiles: improvement proposals. Mater. Des., 31 (2010), pp. 35-41

- Macgee, A. E. The heat required to fire ceramic bodies. Journal of the American Ceramic Society, 9: 206-247, 1926

- Madivate, C.M., Malate, A.M., Verryn, S., Loubser, M. Energy requirement for firing porcelain. Bulletin of the Chemical Society of Ethiopia, 18(1), 73-80, 2004.

- Mezquita, A.; Boix, J.; Monfort, E.; Mallol, G. Energy Saving In Ceramic Tile Kilns: Cooling Gas Heat Recovery. Appl. Thermal Eng. 65 (4), 102-110, 2014.

- Mezquita, A.; Monfort, E.; Zaera, V. Ceramic tiles manufacturing and emission trading scheme: reduction of $\mathrm{CO}_{2}$ emissions, European benchmarking. Bol. Soc. Esp. Ceram. Vidr., 48(4), 211-222, 2009.

- Monfort, E.; Mezquita, A.; Granell, R.; Vaquer, E.; Escrig, A.; Miralles, A.; Zaera, V. Analysis of energy consumption and carbon dioxide emissions in ceramic tile manufacture. Bol. Soc. Esp. Ceram. Vidr., 49(4), 303-310, 2010.

- Njoya, D., Hajjaji, M., Njopwouo, D. Effects of some processing factors on technical properties of a clay-based ceramic material. Appl. clay sci., 65-66 (2012), pp. 106-113. 
- Orts, M.J.; Escardino, A.; Amorós, J.L.; Negre, F. Microstructural changes during the firing of stoneware floor tiles. Appl. clay sci., 8 (2/3), 193-205, 1993.

- Pennisi, L. In Ceramics and Glasses. Engineering Materials Handbook, Vol. 4. ASM International, Materials Park, OH, 1991, pp. 255-259

- Peters, T., Iberg, R. Mineralogical changes during firing of calcium-rich brick clays. American Ceramic Society Bulletin, 57 (1978), p. 504

- Plante, A., Fernández, J.M., Leifeld, J. Application of thermal analysis techniques in soil science. Geoderma, 153, pp. 1-10, 2009.

- Ratzenberger, H., Vogt, S. Possibilities for the prediction of shaping, drying and firing behavior of heavy clays and production bodies ZI - Annual 1993: pp. 70-111.

- Retrieved July 10, 2014, from http://www.dow.com/polyglycols/polyethylene/products/carbowaxp.htm

- Retrieved January 16, 2014, from http://www.icdd.com/

- Riccardi, M. P., Messiga, B., Duninuco, P. An approach to the dynamics of clay firing, Appl. clay sci., 15, 3-4 (1999), pp. 393-409.

- Sánchez, E.; Orts, M.J.; García-Ten, J.; Cantavella, V. Porcelain tile composition effect on phase formation and end products. Am. Ceram. Soc. bull., 80(6), 43-49, 2001.

- Schieltz, N.C., Soliman, M.R. "Thermodynamics of the various high-temperature transformations of kaolinite"; pp, 419-428 in Clays and Clay Minerals. Proceedings of the Thirteenth National Conference, Pergamon, London, 1964.

- Simpson, H. E. The heat required to fire ceramic bodies. Journal of the American Ceramic Society, 10: 897-918, 1927.

- Vaughan, F. Energy changes when kaolin minerals are heated. Clay Minerals. Bull. 2, 265-74, 1955.

- Venturelli, C., Paganelli, M. Sintering behaviour of clays for the production of ceramics. cfi/Ber. DKG 84, No. 5; 2007. 
- Vogt, S., Vogt, R.; Relationship between minerals and the industrial manufacturing properties of natural clay deposits and the clay bodies produced from them for the heavy clay industry (part 2). ZI - Annual 2004: pp. 78-103.

- Vogt, S.; Thomas, R. On the preparation of energy balances for brick and tile-making plants (part 2). ZI Int., 64(10), 12-27, 2012.

- Walters, R. N., Hackett, S. M., Lyon, R. E. (2000), Heats of combustion of high temperature polymers. Fire Mater., 24: 245-252.

- Zevin, L.S., Kimmel, G. Quantitative X-ray Diffractometry. Springer: New York, 1995. 